\title{
POSSIBILITIES FOR THE USE OF WASTE PERLITE IN THE PRODUCTION OF AERATED AUTOCLAVED CONCRETE
}

\author{
MOŽNOSTI UPORABE ODPADKOV PERLITA ZA PROIZVODNJO \\ V AVTOKLAVU PREZRAČENEGA BETONA
}

\author{
Jana Húšt’avová, Pavlína Šebestová, Lenka Mészárosová*, Vít Černý, \\ Rostislav Drochytka \\ Brno University of Technology, Veveř́ 331/95, 60200 Brno, Czech Republic \\ Prejem rokopisa - received: 2019-08-19; sprejem za objavo - accepted for publication: 2020-01-29
}

doi:10.17222/mit.2019.193

\begin{abstract}
The enormous production of both communal and industrial waste is a significant problem of our times. For this reason, seeking ways to utilise such wastes is still topical, hand in hand with efforts for the maximum preservation of natural resources. This paper addresses the possible replacement of sand used for the production of autoclaved aerated concrete. The effects created by the partial and complete replacement of waste perlite filler on the physical-mechanical properties (for example, bulk density, strength) and changes in the microstructure by the replacement of various amounts of primary raw materials $(10,30,50$, and $100) \%$ ) and secondary raw material, i.e., the formation of a porous structure, its characteristics and mineralogical composition, in particular the formation of tobermorite.

Keywords: AAC, composite, waste perlite, tobermorite
\end{abstract}

Dandanes zelo pomemben problem je nastajanje ogromne količine komunalnih in industrijskih odpadkov. Zato se stalno išče nove rešitve za uporabo le-teh pri maksimalni ohranitvi naravnih surovin. V članku avtorji obravnavajo možne zamenjave za pesek, ki se uporablja v proizvodnji betona, prezračenega v avtoklavih. Avtorji so analizirali učinke delne ali popolne zamenjave peska z odpadnim perlitom na fizikalno-mehanske lastnosti, kot sta naprimer volumska gostota in trdnost. Analizirali so spremembe v mikrostrukturi betona pri zamenjavi primarne surovine $\mathrm{z}$ različnimi vsebnostmi $(10,30,50$ in 100$) \%$ perlita, to je tvorbo porozne strukture, njene lastnosti in mineraloško sestavo ter posebej še tvorbo tobermorita.

Ključne besede: $v$ avtoklavih prezračeni beton (AAC), kompozit, odpadki perlita, tobermorit

\section{INTRODUCTION}

Autoclaved aerated concrete (AAC) is a building material that is characterized by a pore structure, high porosity and a low bulk density. The AAC is cured under hydrothermal conditions in an autoclave. To produce AAC, quartz sand, lime, cement, gypsum, and aluminium powder are used. ${ }^{1-5}$ In this paper attention is paid to the sand substitution with waste perlite. It is worth mentioning that perlite is also a building material with a high porosity and a very low bulk density. During the production of perlite, waste material (WEP) is produced, for which re-use is sought. It is a replacement of the crystalline component with an amorphous component. Amorphous silica is more soluble and may react under hydrothermal conditions to form other phases or phases in a different percentage than in the composite with crystalline silica. For this reason, it is necessary to monitor the effect of the replacement on the AAC microstructure and thus on the physical and mechanical properties.

Waste perlite (WEP) contains, besides $\mathrm{SiO}_{2}$, also $\mathrm{Al}_{2} \mathrm{O}_{3}$, which makes it one of the pozzolanic reactive materials. ${ }^{6-9}$ Based on this property, various substitution

*Corresponding author's e-mail:

meszarosova.1@fce.vutbr.cz (Lenka Mészárosová) options and areas of application for WEP have already been explored. For example, W. Long et al. ${ }^{10}$ studied the effect of WEP on the hydration process and hence on the physico-mechanical properties of alkali-activated slag composites using WEP (WEP-AASC). They experienced a decrease in the compressive strength with increasing amounts of WEP replacement; however, no changes in the reaction products appeared. On the other hand, Kotwica et al. ${ }^{11}$ noted an increase in the compressive strength of the WEP admixture cement composite, even by $50 \%$, with a $35 \%$ WEP admixture. Strength increases have also been observed by V. pet al. ${ }^{8}$ after the addition of WEP to hydraulic injection composites. F. Guenanou et al. ${ }^{7}$ studied the pozzolanic activity of perlite powder and its effect on cement composites. They were able to demonstrate the pozzolanic activity of perlite in the presence of calcium silicate hydrates (CSHs), calcium aluminate hydrates and hydrated gehlenite. They also determined the optimum fraction of perlite in the composite at 10-20\%. This amount improved the resistance of the composite to an aggressive environment due to the reduced porosity and water absorption.

The use of WEP in AAC is still a little-researched area. A. Fabien et al. ${ }^{6}$ investigated the properties of non-autoclaved aerated concrete in WEP. The substitution rate was $30 \%$. Since perlite has a low bulk 


\section{J. HÚŠŤAVOVÁ et al.: POSSIBILITIES FOR THE USE OF WASTE PERLITE IN THE PRODUCTION OF ...}

density, it has been assumed that by substituting perlite for sand, it will improve the thermal insulation conditions. Their assumption was confirmed, but the presence of WEP had a negative impact on the compressive strength. On the other hand, increasing the amount of cement by $2 \%$ increased the compressive strength by $21 \%$. According to their results, $10 \%$ perlite sand substitution should not influence the compressive strength, but at a $30 \%$ substitution, they have already experienced a $20 \%$ decrease in compressive strength. On the other hand, WEP had a positive effect on the formation of tobermorite.

\section{EXPERIMENTAL PART}

This study is supplemented with the findings of the effect of WEP on a non-aerated calcium silicate composite (LSC). The mix proportion of raw materials was selected from real AAC production, but in the production of LSC, aluminum powder, which is commonly used as a foaming agent, was omitted. The reason was to monitor the extent to which WEP can be used in a substitution to reduce the bulk density. Quartz sand, which is a source of crystalline $\mathrm{SiO}_{2}$, is gradually substituted by WEP, which is a source of amorphous $\mathrm{SiO}_{2}$. A $10 \%$, $30 \%$, $50 \%$ and $100 \%$ volume substitution was selected.

\subsection{Materials}

Quartz sand, unslaked lime, Portland cement CEM I $52.5 \mathrm{~N}$, gypsum and aluminum powder in the case of AAC were used for the production of lime-silicate composites. The quartz sand was selected with respect to the maximum amount of silica $\left(\mathrm{SiO}_{2}\right)$ and the minimum of other minerals, especially clay minerals. From the chemical point of view, the sand used contained $92 \% \mathrm{SiO}_{2}$. For the AAC production, the sand was ground to a specific surface of $2700 \mathrm{~cm}^{2} / \mathrm{g}$. The lime contained $95 \%$ calcium oxide $(\mathrm{CaO})$. In the reactivity test, lime reached $60{ }^{\circ} \mathrm{C}$ in $6 \mathrm{~min}$, which meets the technological requirement. Calcium sulfate from thermal combustion was used as a source of calcium sulfate. The calcium sulfate content in the gypsum was $90 \%$. The WEP density was determined to be $300 \mathrm{~kg} / \mathrm{m}^{3}$. Its chemical composition is shown in Table 1.

\subsection{Ratio of raw materials}

The primary raw-material ratios utilized are shown in Table 2. Waste perlite was utilised as a $10 \%, 30 \%$, $50 \%$ and $100 \%$ replacement of the silica sand.

\subsection{Preparation process}

For the production of the AAC, the dry reactive components (lime, cement), sand suspension (sand, gypsum, water) and aluminium suspension (powdered aluminium, degreasing agent, water) were first homogenized separately. Then the sand suspension was preheated to $40{ }^{\circ} \mathrm{C}$. The preheated sand suspension and the dry reactive components were mixed. Mixing was performed for $60 \mathrm{ss}$. The aluminium suspension was added last. The resulting mixture was stirred for an additional $60 \mathrm{~s}$. The mixture was poured into forms of $(100 \times 100 \times 100) \mathrm{mm}$ and put into a drying room at $40{ }^{\circ} \mathrm{C}$. After $24 \mathrm{~h}$, the AAC blocks were placed in an autoclave.

The preparation of the LSC was like the preparation of the AAC. The main difference was in the absence of any aluminium powder. Furthermore, the sample size for the LSC was chosen to be $(20 \times 20 \times 100) \mathrm{mm}$.

Both AAC and LSC were autoclaved simultaneously in the same autoclave to keep the same hydrothermal conditions. As the autoclaving temperature, $190{ }^{\circ} \mathrm{C}$, was selected and the time under hydrothermal conditions was $7 \mathrm{~h}$. These conditions correspond to the real AAC production. The amount of water was constant to observe the effect of WEP on the suspension rheology.

\subsection{Methods}

The compressive strength was determined according to EN 679, "Determination of compressive strength of autoclaved concrete".

The bulk density was determined in accordance with EN 678, "Determination of the volume of dry autoclaved aerated concrete".

Flow tests of the green AAC suspension were performed by means of a cylinder measuring $5.4 \mathrm{~cm}$ in height, $7.1 \mathrm{~cm}$ in diameter. The suspension was poured into the cylinder and after its lift two perpendicular diameters of the spreading suspension were measured.

Table 1: Chemical composition of WEP

\begin{tabular}{|c|c|c|c|c|c|c|c|c|c|c|}
\hline Oxide & $\mathrm{CaO}$ & $\mathrm{MgO}$ & $\mathrm{K}_{2} \mathrm{O}$ & $\mathrm{Al}_{2} \mathrm{O}_{3}$ & $\mathrm{P}_{2} \mathrm{O}$ & $\mathrm{Fe}_{2} \mathrm{O}_{3}$ & $\mathrm{MnO}$ & $\mathrm{Na}_{2} \mathrm{O}$ & $\mathrm{SiO}_{2}$ & $\mathrm{TiO}_{2}$ \\
\hline$(\%)$ & 1.26 & 0.228 & 4.56 & 13.1 & $<0.023$ & 2.02 & 0.057 & 2.14 & 74.0 & 0.157 \\
\hline
\end{tabular}

Table 2: Raw-materials mixture references sample

\begin{tabular}{|c|c|c|c|c|c|}
\hline \multirow{2}{*}{ Raw materials } & Lime & Cement & Calcium sulfate & Quartz sand & Aluminum powder \\
\cline { 2 - 6 } & \multicolumn{5}{|c|}{$(w / \%)$} \\
\hline AAC & 2.1 & 3.2 & 17.6 & 77.1 & 77.1 \\
\hline LSC & 2.1 & 3.2 & 17.6 & - \\
\hline
\end{tabular}


Optical microscopy. A Keyence VHX-950F optical digital microscope was used, it has a CMOS image sensor with $1600(\mathrm{H}) \times 1200(\mathrm{~V})$ virtual pixels, a frame rate of $50 \mathrm{~F} / \mathrm{s}$ and a maximum magnification of $67.7 \times$.

X-ray diffraction analysis (XRD) was used to study the microstructure of the AAC and LSC. XRD consists of measuring the angle Theta at a known wavelength Alpha. The specific spacing value d of a given mineral can thus be determined. The samples were mechanically cleaned and ground to a fine powder with a maximum grain size of $20 \mu \mathrm{m}$.

Scanning electron microscopy. To complete the microstructure study, scanning electron microscopy (SEM) images were added to the XRD diagram. AAC and LSC fragments of $(5 \times 5 \times 5)$ mm were selected for this purpose. A TESCAN MIRA3 XMU was used for SEM.

\section{RESULTS AND DISCUSSION}

\subsection{Physical - mechanical properties}

\subsubsection{Flow behaviour}

First, a consistency test was performed on each recipe. The mixture contained a constant amount of water to compare the effect of the WEP on consistency. At a low viscosity of the mixture, the hydrogen gas formed does not bind to the microporous binder matrix, and the gas escapes from the mixture before its hardening. Imperfect aeration also occurs at too high a viscosity. In such a case, the hydrogen gas is incompletely dispersed in the AAC suspension and the high pressure of the microporous binder matrix flocculates the gas. This creates large pores and the porous concrete loses its thermal insulating property. ${ }^{12}$ The results of the flow test are shown in the summary graph of Figure 2.

The dependence of consistency on the amount of WEP can be observed based on a flow test. As WEP sand substitution increases, the viscosity of the mixture decreases. This dependence was observed up to $30 \%$ WEP. The addition of $10 \%$ WEP had no effect on the consistency. It should be noted that the viscosity of the high WEP blend was expected to be higher. However, the low viscosity is only apparent, and when the air layer breaks around the perlite grains, the water is rapidly absorbed, the suspension thickens, resulting in imperfect aeration. This phenomenon can be observed in a sample with a $100 \%$ WEP substitution. The graphs show a decrease in the pore content mainly in the lower part of the sample and at the same time to a significant increase in the pore size, mainly in the middle of the sample

\subsubsection{Compressive strength and bulk density}

Depending on the amount of WEP substitution, the bulk density and compressive strength are monitored. The compressive strength of the samples increases to $30 \%$ of the values of the compressive strength of the reference sample strength. From the $50 \%$ WEP content, the strength of the sample is already decreasing. The AAC samples were shown to be dependent on the WEP content, despite the increased bulk density of the sample with a $50 \%$ WEP substitution.

A sample with $50 \%$ WEP substitution achieves a higher bulk density. This phenomenon caused the leakage of hydrogen gas before the microporous binder matrix's hardening. This phenomenon was also confirmed by the number of pores shown in Figure 2. With a $50 \%$ WEP substitution, a decrease in the total pore content as well as a decrease in the average pore size can be observed. Therefore, it can be concluded that the viscosity of the mixture was too high. The $100 \%$ WEP sample had the lowest bulk density. The low bulk density of a $100 \%$ substitution sample is also due to the total replacement of silica sand with a very low bulk density material.

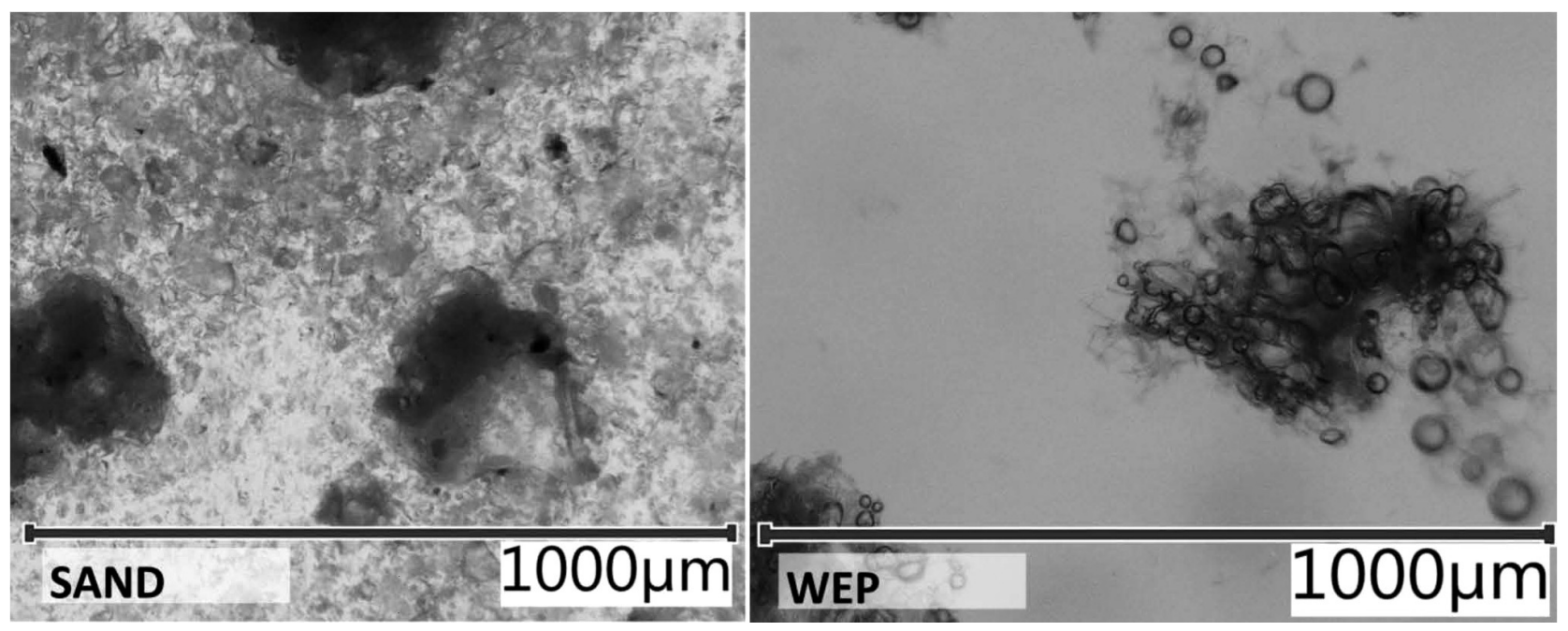

Figure 1: Image of admixture of water suspension of WEP and quartz sand 


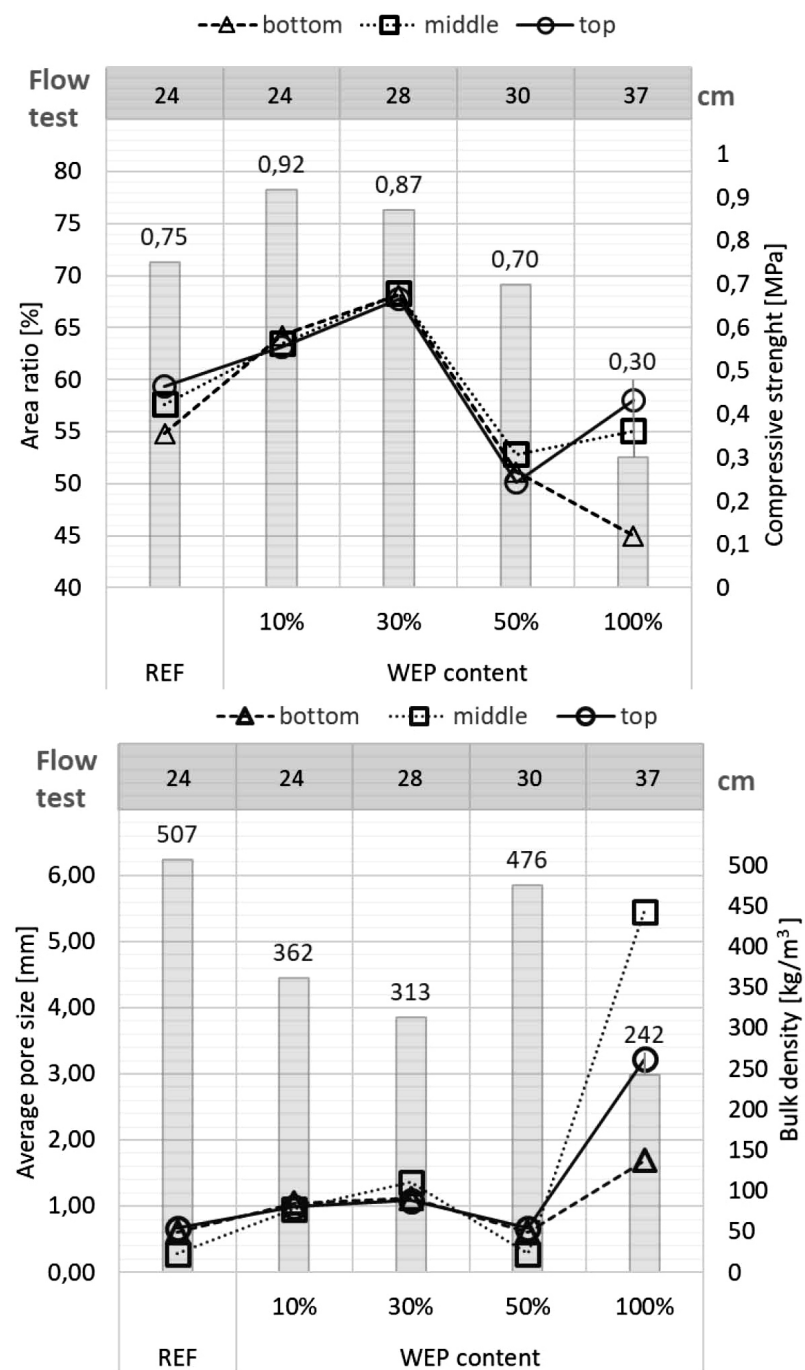

Figure 2: Area ratio, average pore size, compressive strenght, bulk density and flow test of reference sample and samples with WEP substitution

\subsubsection{Porous structure}

The formation of the air layer was monitored using an optical microscope (Figure 1). The picture shows silica sand and WEP after the homogenization with water.

The total amount of pores in the reference sample is $63 \%$ and their average size is up to $1 \mathrm{~mm}$. The macropores in the AAC are defined from a size of $0.06 \mathrm{~mm}$ and significantly affect the physical-mechanical properties. ${ }^{12-14}$

At $10 \%$ and $30 \%$ admixture, the total porosity of the sample increases, while the average pore size increases. In correlation with an increasing porosity, the bulk density of the sample also decreases. However, the compressive-strength values increase with a lower bulk density and a higher porosity. This statement applies to samples with the $10 \%$ and $30 \%$ WEP substitutions. The explanation of the increasing strengths is likely to be

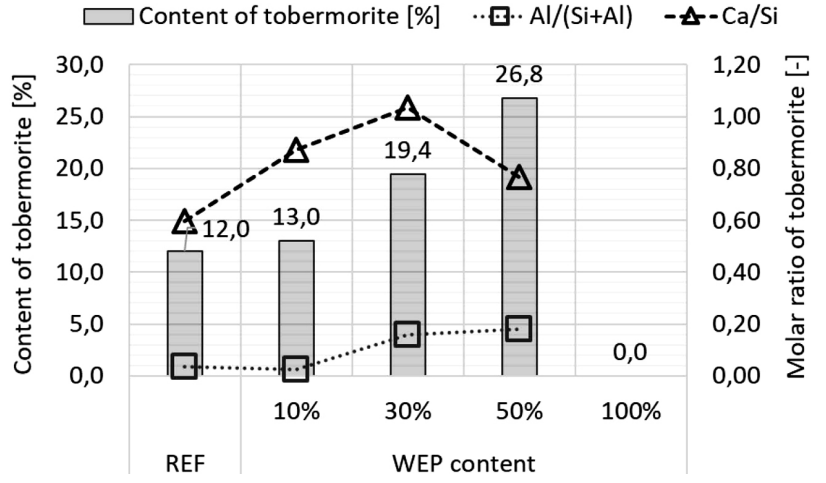

Figure 3: Content and molar ratio of tobermorite from the reference sample and the samples with WEP substitution

related to the microstructure of the sample, as described below.

The same measurement results in three different parts of the sample indicate an even pore distribution. The different pore content and size is present only in the sample with a $100 \%$ WEP substitution.

\subsubsection{Microstructure}

The microstructures of the AAC and LSC were studied by a quantitative determination of the minerals using a Rietveld refinement from the XRD diffractogram. The approximate calculated tobermorite content was monitored. The values are indicated in a graph (Figure 3).

In the AAC samples there was an increased amount of tobermorite with an increasing WEP content up to a $50 \%$ substitution. At $100 \%$ WEP, the AAC samples

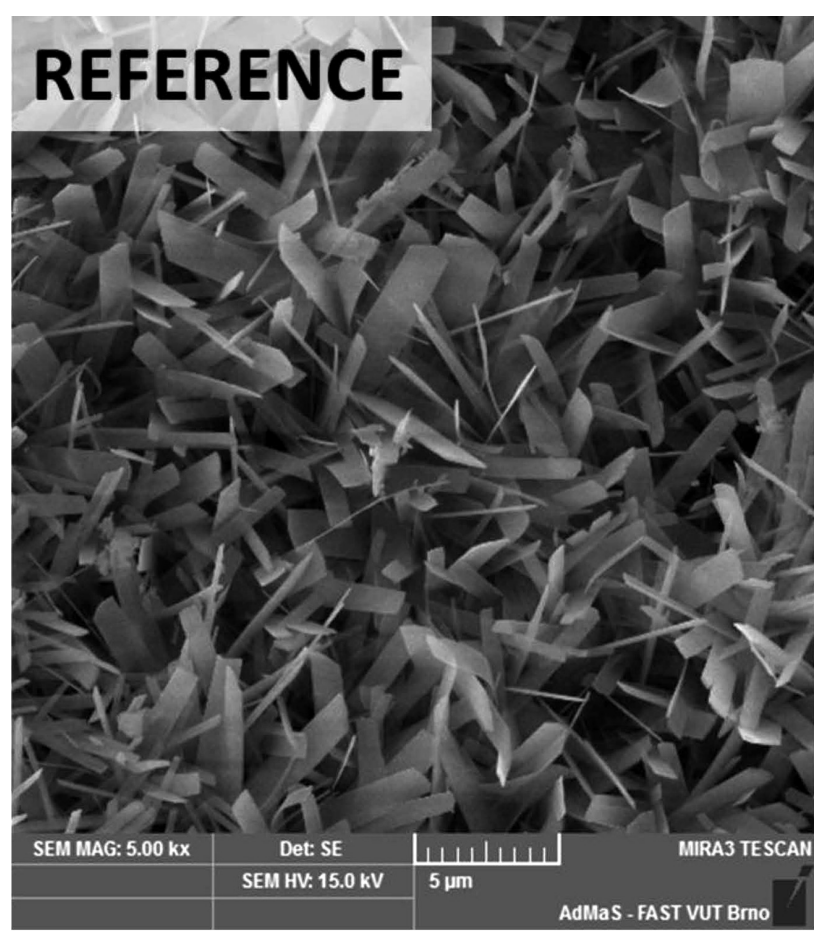

Figure 4: SEM image of reference sample 


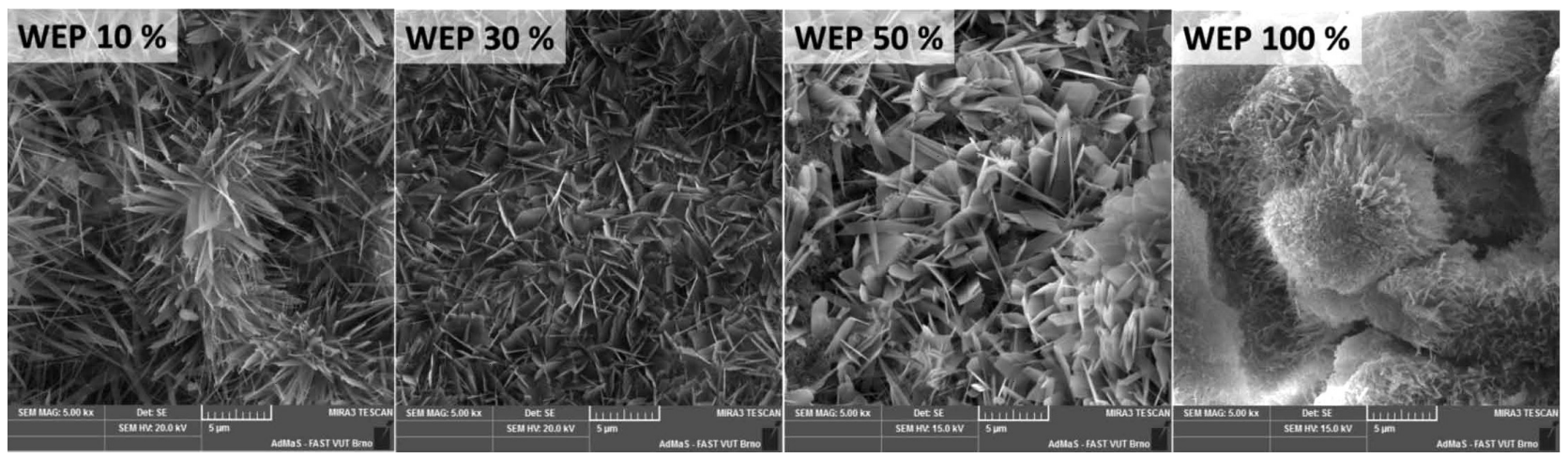

Figure 5: SEM image of sample with WEP substitution

showed no tobermorite. The reason for these effects is probably the character of WEP. Up to $50 \%$ WEP substitution, amorphous $\mathrm{SiO}_{2}$ stimulated the formation of tobermorite. Tobermorite is easier to form and at lower temperatures when the $\mathrm{SiO}_{2}$ source is amorphous. At the same time, the grain size and the specific surface area also have an effect. Since WEP is a fine-grained raw material with a high specific surface area, it is more soluble and reacts more rapidly in the hydrothermal environment to form new CSH phases. ${ }^{15,16}$ Based on the results of the XRD analysis, a combination of crystalline and amorphous $\mathrm{SiO}_{2}$ is needed to promote the formation of the tobermorite.

This finding is supported by SEM images. A change in the morphology of tobermorite can be observed with the increasing proportion of WEP (Figure 5). Thick,

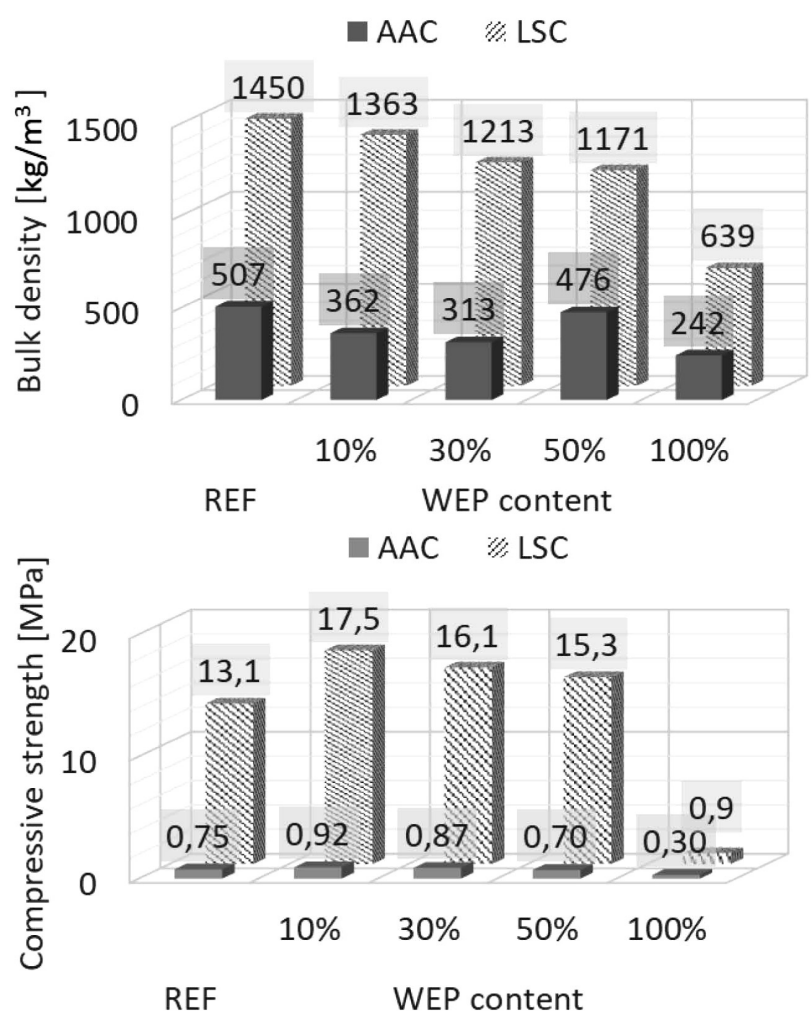

Figure 6: Compressive strength and bulk density of AAC and LSC long tobermorite crystals are visible in the reference sample (Figure 4). At a $10 \%$ substitution, they became smaller and the content was reduced, at $30 \%$ the tobermorite crystals were already plate-like. At a $50 \%$ substitution, the crystals were still visible as plate-like, but of larger dimensions. No tobermorite was observed at $100 \%$ substitution.

It follows from the above that the compressive strength of the AAC samples is not dependent on the amount of tobermorite contained in the sample. In order to achieve the required AAC strengths using WEP, it is necessary to maintain a suitable proportion of the sand as a filler. In this case, a maximum WEP substitution limit of $30 \%$ can be established.

\subsubsection{Comparison of AAC and LSC}

The results of LSC and AAC are compared in Figure 6.

The sample bulk density (Figure 6) of the AAC was approximately $30 \%$ of the bulk density of the LSC samples. The bulk density values of the LSC showed a decrease depending on the amount of WEP. Interestingly, the LSC sample with $100 \%$ WEP showed a more than $50 \%$ lower bulk density. It can be assumed that a low bulk-density composite could be achieved even without loosening.

The compressive strengths of the LSC samples were approximately $6 \%$ of the compressive strengths of the AAC. In the LSC sample, an increase in the compressive strength was observed with replacements of $10 \%, 30 \%$ and $50 \%$ sand by WEP. $100 \%$ WEP then showed a marked decline. The decrease in strength is caused by the physical mechanical structure of the raw-material WEP, which achieves a lower mechanical strength than the sand itself. Further, it can be assumed that the development of the microstructure is similar to that of the AAC and thus the binder crystalline phase is absent in the sample. Thus, WEP is associated only with non-crystalline $\mathrm{CSH}$ phases. 


\section{J. HÚŠŤAVOVÁ et al.: POSSIBILITIES FOR THE USE OF WASTE PERLITE IN THE PRODUCTION OF ...}

\section{CONCLUSION}

The study of the influence of the substitution of WEP for silica sand in AAC technology has brought an interesting finding. The results show that the maximum beneficial amount of WEP is $30 \%$. Up to this limit, WEP has a positive effect on the even distribution of pores in the matrix, with a zero-phase content of more than $65 \%$. Furthermore, the positive impact of WEP on the compressive strength of AAC was observed, where the values increased, and at the same time a decrease in the bulk density was observed. AAC using WEP has a high potential as a building-insulation material. Likewise, one can see an interesting isolation potential of the non-aerated lime silica composites made with $100 \%$ WEP substitution, which achieved a bulk density value comparable to the commercially produced AAC. This finding opens up further study possibilities in the future.

\section{Acknowledgment}

This paper was prepared as part of a Czech Science Foundation (GACR) project with the identification code GA17-14198S "Kinetics of silicon micro-structure creation in dependence on hydrothermal conditions and type of used materials" and by the project FAST-S-195779 "Problems of effective use of secondary raw materials in the area of silicate and non-silicate based composites".

\section{REFERENCES}

${ }^{1}$ H. Kurama, İ. B. Topçu, C. Karakurt, Properties of the autoclaved aerated concrete produced from coal bottom ash. Journ. of Mater. Proc. Techn., 209 (2009) 2, 767-773, doi:10.1016/j.jmatprotec. 2008.02.044

${ }^{2}$ P. Walczak, J. Malolepszy, M. Reben, P. Szymański, K. Rzepa, Utilization of Waste Glass in Autoclaved Aerated Concrete. Proc. Eng., 122 (2015) 302-309, doi:10.1016/j.proeng.2015.10.040

${ }^{3}$ P. Walczak, P. Szymański, A. Różycka, Autoclaved Aerated Concrete based on Fly Ash in Density $350 \mathrm{~kg} / \mathrm{m}^{3}$ as an Environmentally Friendly Material for Energy - Efficient Constructions. Proc. Eng., 122 (2015) 39-46, doi:10.1016/j.proeng.2015.10.005
${ }^{4}$ L. Cai, B. Ma, X. Li, Y. LV, Z. Liu, S. Jian, Mechanical and hydration characteristics of autoclaved aerated concrete (AAC) containing iron-tailings: Effect of content and fineness. Constr. and Build. Mat., 218 (2016) 361-372, doi:10.1016/j.conbuildmat.2016. 10.031

${ }^{5}$ Y. Song, Ch. Guo, J. Qian, T. Ding, Effect of the Ca-to-Si ratio on the properties of autoclaved aerated concrete containing coal fly ash from circulating fluidized bed combustion boiler. Constr. and Build. Mat., 83 (2015) 136-142, doi:10.1016/j.conbuildmat.2015.02.077

${ }^{6}$ A. Fabien, N. Sebaibi, M. Boutouil, Effect of several parameters on non-autoclaved aerated concrete: use of recycling waste perlite, Europ. Journal of Env. and Civ. Eng. (2019) 1-18, doi:10.1080/ 19648189.2019.1647465

${ }^{7}$ F. Guenanou, H. Khelafi, A. Aattache. Behavior of perlite-based mortars on physicochemical characteristics, mechanical and carbonation: Case of perlite of Hammam Boughrara, Journal of Build. Eng., 24 (2019), doi:10.1016/j.jobe.2019.100734

${ }^{8}$ V. Patcha, F. Papadopoulos, M. Stefanidou, Development and testing of grouts based on perlite by-products and lime, Constr. and Build. Mat., 207 (2019) 338-344, doi:10.1016/j.conbuildmat.2019.02.157

${ }^{9}$ A. Różycka, W. Pichór, Effect of perlite waste addition on the properties of autoclaved aerated concrete, Constr. and Build. Mat., 120 (2016) 65-71, doi:10.1016/j.conbuildmat.2016.05.019

${ }^{10}$ W. Long, X. Tan, B. Xiao, N. Han, F. Xing, Effective use of ground waste expanded perlite as green supplementary cementitious material in eco-friendly alkali activated slag composites, Journ. of Cl. Prod., 213 (2019) 406-414, doi:10.1016/j.jclepro.2018.12.118

${ }^{11}$ L. Kotwica, W. Pichór, W. Kapeluszna, A. Różycka, Utilization of waste expanded perlite as new effective supplementary cementitious material, Journ. of Cl. Prod., 140 (2017) 1344-1352, doi:10.1016/ j.jclepro.2016.10.018

${ }^{12}$ N. Narayanan, K. Ramamurthy, Structure and properties of aerated concrete: a review, Cem. and Con. Comp., 22 (2000) 321-329, doi:10.1016/S0958-9465(00)00016-0.

${ }^{13}$ I. Petrov, E. Schlegel. Application of automatic image analysis for the investigation of autoclaved aerated concrete structure, Cem. and Con. Res., 24 (1984) 830-840, doi:10.1016/0008-8846(94)90003-5

${ }^{14} \mathrm{~J}$. Alexanderson, Relations between structure and mechanical properties of autoclaved aerated concrete, Cem. and Con. Res., 9(4) (1979) 507-514, doi:10.1016/0008-8846(79)90049-8.

${ }^{15}$ D.S. Klimesch, A. Ray, Effects of quartz particle size on hydrogarnet formation during autoclaving at $180{ }^{\circ} \mathrm{C}$ in the $\mathrm{CaO}-\mathrm{Al}_{2} \mathrm{O}_{3}-\mathrm{SiO}_{2}-\mathrm{H}_{2} \mathrm{O}$ system, Cem. and Con. Research. 28 (1998) 1309-1316, doi:10.1016/S0008-8846(98)00112-4.

${ }^{16}$ N. Isu, H. Ishida, T. Mitsuda, Influence of quartz particle size on the chemical and mechanical properties of autoclaved aerated concrete (I) tobermorite formation, Cem. and Con. Res., 25 (1995) 243-248, doi:10.1016/0008-8846(95)00003-8 